\title{
Seismogenic structure and processes associated with magma inflation and hydrothermal circulation beneath the East Pacific Rise at $9^{\circ} 50^{\prime} \mathrm{N}$
}

\author{
Felix Waldhauser and Maya Tolstoy \\ Lamont-Doherty Earth Observatory, Columbia University, Palisades, New York 10964, USA \\ (felixw@ldeo.columbia.edu; tolstoy@ldeo.columbia.edu)
}

[1] A dense ocean bottom seismometer array recorded more than 7,300 microearthquakes between October 2003 and April 2004 on the fast spreading East Pacific Rise at $9^{\circ} 50^{\prime} \mathrm{N}$. A previous initial analysis of these data revealed the general structure of an along-axis oriented hydrothermal circulation cell, with an inferred down-flow zone near a 4th-order axial discontinuity, a horizontal band of seismicity overlying the axial magma chamber (AMC), and an upflow zone that correlates with activity patterns of hydrothermal vents. Here we present cross-correlation-based double-difference hypocenter locations that reveal further insight into the detailed structure and kinematics that control seismic failure. We find that the majority of events within the inferred down flow pipe occur near the surface where the entrenched seawater presumably lowers the frictional strength of faults generated by local tectonic stresses. Beneath the eastern side of the ridge axis, just above the AMC at $\sim 1.4 \mathrm{~km}$ depth, we observe repeated shear failure along well defined steeply east dipping faults. Composite focal mechanisms indicate reverse motion, suggesting that slip on these faults is caused by AMC inflation and possibly injection of magma into a narrow sill. We resolve a small counterclockwise skew in the strike of the reverse faults relative to the direction of the ridge axis, consistent with Nuvel 1A spreading direction suggesting that the regional tectonic stress field may be controlling the seismogenic structures at depth. Earthquakes on the reverse faults occur preferentially during peak extensional tidal stresses, indicating that these faults are critically stressed.

Components: 8200 words, 12 figures.

Keywords: East Pacific Rise; active faulting; earthquake location; hydrothermal circulation; magma; seismicity.

Index Terms: 3017 Marine Geology and Geophysics: Hydrothermal systems (0450, 1034, 3616, 4832, 8135, 8424); 3035 Marine Geology and Geophysics: Midocean ridge processes; 7245 Seismology: Mid-ocean ridges.

Received 17 February 2011; Revised 11 July 2011; Accepted 12 July 2011; Published 3 September 2011.

Waldhauser, F., and M. Tolstoy (2011), Seismogenic structure and processes associated with magma inflation and hydrothermal circulation beneath the East Pacific Rise at 950’N, Geochem. Geophys. Geosyst., 12, Q08T10, doi:10.1029/2011GC003568.

Theme: Recent Volcanic Eruptions, Properties, and Behavior of the EPR, $8^{\circ}-11^{\circ} \mathrm{N}$

\section{Introduction}

[2] Seismogenic processes along extensional segments of fast spreading Mid Ocean Ridges (MOR) typically take place undetected by global seismic networks. Earthquake monitoring experiments using ocean bottom seismometers (OBS) placed near the ridge axis on fast spreading ridges have shown that 

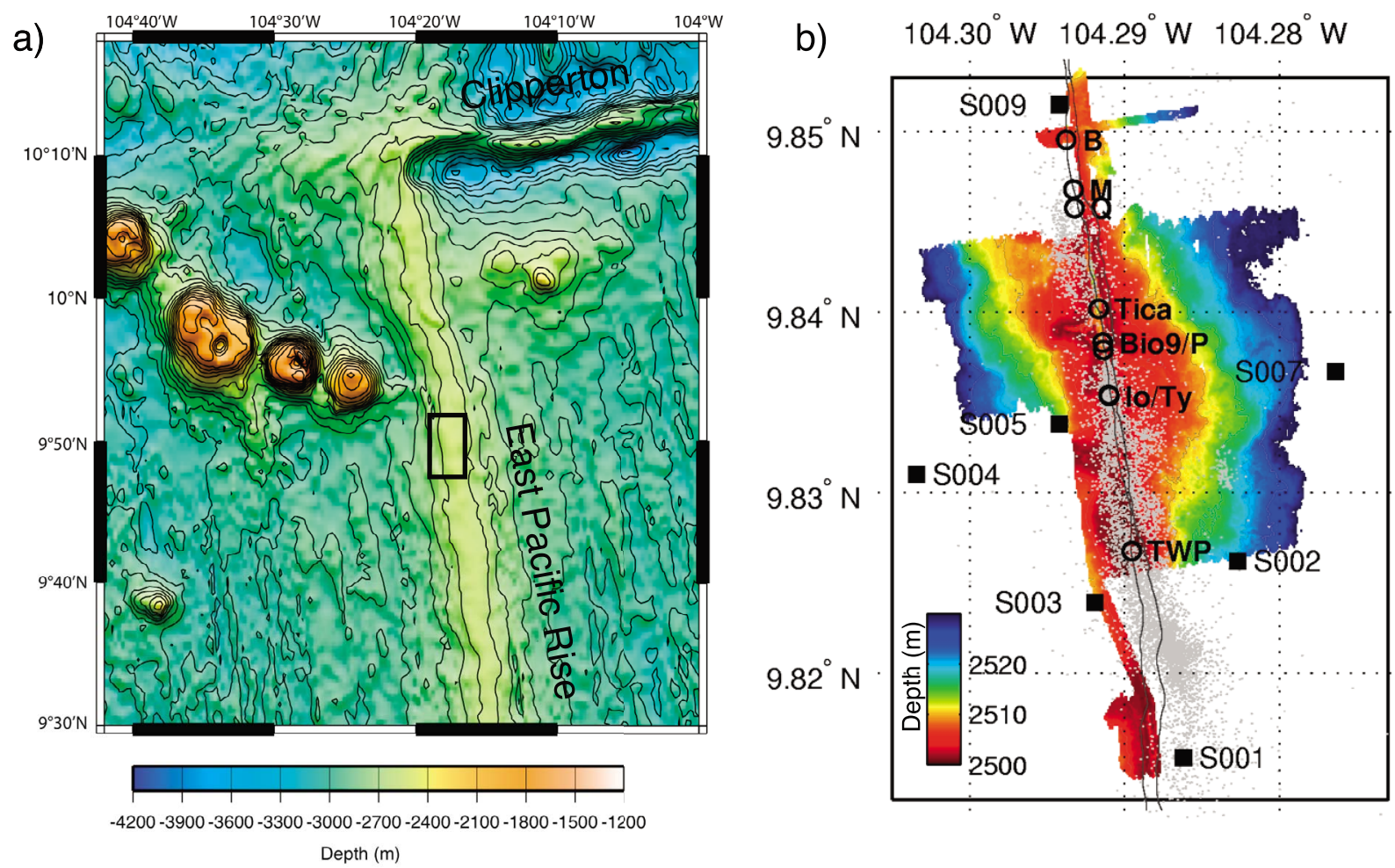

Figure 1. (a) Bathymetry map of the East Pacific Rise near $9^{\circ} 50^{\prime} \mathrm{N}$. Black box denotes study area. (b) Map showing station locations (squares), epicenter locations (gray dots), axial summit trough (thin black lines), and high-temperature vents (circles). High-resolution bathymetry map from side scan survey [Ferrini et al., 2007] is shown where available.

microearthquakes occur at levels mostly below magnitude $\mathrm{M}_{\mathrm{L}}=2$ and are largely inferred to be associated with tectonic, magmatic, or hydrothermal processes, or a combination of all [e.g., Sohn et al., 1999; Tolstoy et al., 2006, 2008; Wilcock et al., 2009]. The high cost and technical challenges of deploying long-term seafloor seismic arrays have limited the longer-term characterization of the spatiotemporal behavior of seismogenic processes at mid-ocean ridges. Long-term images of seismic activity are particularly important to study the structure and dynamics of crustal extension, and the tectonic, magmatic, and hydrothermal processes that control it. Long-term studies at slow [e.g., deMartin et al., 2007], intermediate [e.g., McClain et al., 1993; Golden et al., 2003; Wilcock et al., 2002, 2009] and fast spreading ridges [e.g., Sohn et al., 1999; Tolstoy et al., 2006, 2008] have all shown high levels of microearthquakes beneath hydrothermal vent sites interpreted as a hydrothermal cracking zone where fluids and hot rock are interacting.

[3] Recent work at the Endeavor segment of the Juan De Fuca ridge has shown a pattern of ridge parallel compressive and extensional focal mechan- isms [Wilcock et al., 2009]. This pattern is consistent with the stresses that would result above the melt lens from a recent injection of magma into the melt lens. Wilcock et al. [2009] hypothesize that this deformation associated with injection of magma may be required to keep the hydrothermal field active by continually cracking and thinning the thermal boundary layer. Without some kind of thinning processes the thermal boundary layer would thicken from below due to freezing of the roof of the magma chamber and from above due to clogging of cracks through mineralization. Thus it might be predicted that sites with active hydrothermal venting should be undergoing magma injection, and show similar patterns of deformation.

[4] A long-term seismic monitoring experiment has been carried out between October 2003 and January 2007 on the East Pacific Rise (EPR) at $9^{\circ} 50^{\prime} \mathrm{N}$ (Figure 1a), a site of robust black smoker venting and volcanism [e.g., Haymon et al., 1993; Rubin et al., 1994; Tolstoy et al., 2006; Cowen et al., 2007] and extensive focused interdisciplinary study for almost two decades. The site has recently been a focus area of the National Science Foundation's 
RIDGE 2000 program, providing an interdisciplinary framework for biological, chemical, and geophysical research [e.g., Lutz et al., 2008]. An array of up to twelve continuously recording OBS stations was deployed to cover a tightly focused area of approximately $4 \times 4 \mathrm{~km}$ across the ridge axis. The instruments were replaced three times on yearly turnaround cruises, with several days of overlap between individual deployments. The OBS array captured the build up of seismicity leading to a seismic crisis in January 2006 associated with a seafloor spreading event that buried 8 of 12 instruments deployed during the third deployment [Tolstoy et al., 2006]. The site erupted previously in 1991-92 [Haymon et al., 1993; Rubin et al., 1994].

[5] The unexpected high number of an estimated 200,000 earthquakes recorded during the four deployments caused a processing bottleneck. We have so far been able to process data from the first deployment and hand-picked arrival times of $\mathrm{P}$ and $\mathrm{S}$ waves at 7 stations (out of 9 deployed) for $\sim 16,000$ recorded earthquakes between October 2003 - April 2004. More than 7,300 of these earthquakes locate within the array and are subject to this study (Figure 1b). In a previous study we carried out an initial pick-based double-difference location analysis of these data which revealed seismic evidence for along-axis hydrothermal circulation cells, with inferred down-flow and up-flow zones that correlate with fourth-order segmentation features and the location and activity patterns of hydrothermal vents, respectively [Tolstoy et al., 2008]. These results do not support the general model of hydrothermal circulation in which water enters the crust along off-axis normal faults and feeds on-axis hydrothermal venting. If such off-axis feeding of hydrothermal fluid occurs, it is not accompanied by seismic activity. The tidal triggering of many of these earthquakes at peak extension indicates that the system is critically stressed due to magmatic and hydrothermal processes [Stroup et al., 2007, 2009]. A b value analysis revealed that stress conditions and/or structural heterogeneity vary at subkilometer scales, but that the first-order spatial pattern of $b$ values is sustained through the 6 months observational period [Bohnenstiehl et al., 2008].

[6] In this paper we build on our previous work and employ waveform cross-correlation methods in the double-difference relocation procedure to resolve and characterize the fine-scale structure of seismicity. The new locations presented here image in detail (tens of meter resolution) the seismogenic structures and properties of the high-temperature hydrothermal reaction zones. We use location, correlation, and focal mechanism information to discriminate between the different modes of failure and their implication for the nature of the stress field that controls crustal extension at the $9^{\circ} 50^{\prime}$ segment of the EPR. We focus on seismic signals that exhibit impulsive onsets and a frequency content that is typical of abrupt frictional slip in tectonic double-couple earthquakes. In fast spreading mid-ocean ridge environments they may also be generated by magmatic or fluid induced abrupt tensile failure (crack opening) with non-doublecouple source mechanisms that include a positive (or negative) volumetric component [Julian et al., 1997]. We find that while slip on the apparently mature faults at depth is likely controlled by the regional tectonic stress field and by stress imposed by ascending magma, the occurrence of most other events is driven by very localized heterogeneous stress conditions that are likely controlled by smallscale fluid movement.

\section{Data and Methods}

[7] The first OBS array deployment, consisting of 9 two-component (vertical and hydrophone) instruments within an approximately $4 \times 4 \mathrm{~km}$ area, recorded continuously with a sampling rate of 125 samples per second between October 2003 and April 2004 (Figure 1) [Tolstoy et al., 2008]. The OBSs were freefall deployed and located to an accuracy of $\sim 10 \mathrm{~m}$ using R/V Atlantis' shipboard acoustic ranging tool. The data has been processed using the Antelope system, with arrival times for $76,000 \mathrm{P}$ and 48,000 $\mathrm{S}$ waves manually picked and associated to some 16,000 events. Events within the array (7.342; $\mathrm{ML}=-0.9-1.2)$ were located one at a time with Hypoinverse [Klein, 2002], using a layered 1D model and station corrections to account for station elevation and velocity structure variations beneath each station. The model and station corrections are obtained from a simultaneous inversion of the arrival times of some 400 well-recorded events for changes in hypocenter location, layer velocities, and station corrections (Velest [Kissling et al., 1994]). A starting model was derived from active source data [Vera et al., 1990] (Figure 2). We use the double-difference algorithm hypoDD of Waldhauser [2001] to improve the resolution of the Hypoinverse locations. hypoDD minimizes, in an iterative least squares sense, residuals between observed and calculated phase delay times between pairs of nearby events recorded at common stations, thus removing bias due to model errors in the single- 

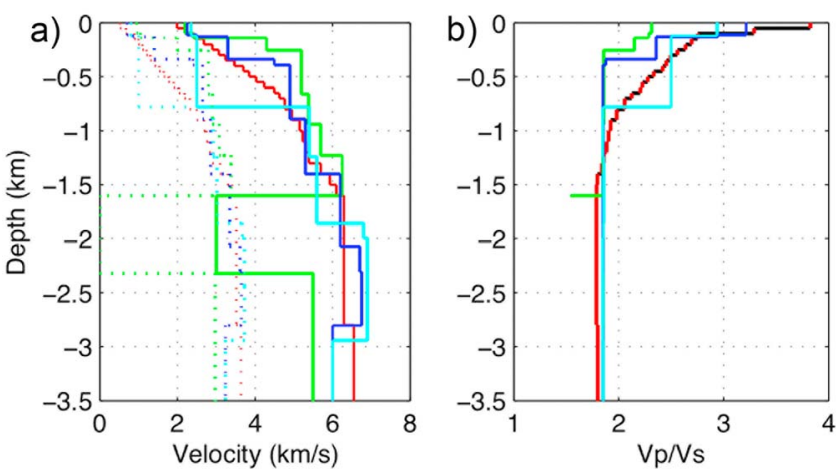

Figure 2. Depth-dependent (a) Vp (solid) and Vs (dashed) and (b) Vp/Vs velocity models from Vera et al. [1990] (green, esp5, on axis; cyan, esp7, east of axis; blue, esp8, west of axis). Red indicates the resampled velocity model used in the DD analysis derived from simultaneous inversion of the arrival times for changes in hypocenter locations, layer velocities, and station corrections, using the Vera et al. [1990] velocities as starting values.

event locations [Waldhauser and Ellsworth, 2000]. We compute delay times from the phase pick data and, with higher precision, from cross correlating similar $\mathrm{P}$ and $\mathrm{S}$ wave trains.

\subsection{Cross-Correlation Delay Time Measurements}

[8] Waveforms recorded at common stations can be similar when the events are separated by small distances (i.e., travel similar paths for most of the time) and have similar source mechanisms. The P and $\mathrm{S}$ wave trains can then be precisely aligned and the phase delay times measured with subsample accuracy in the optimal case [e.g., Poupinet et al., 1984]. We cross correlate, using a time domain cross-correlation method [Schaff et al., 2004; see also Van Decar and Crosson, 1990; Dodge et al., 1995], all possible pairs ( $\sim 54$ million) from the 7,342 events within the array using $1.28 \mathrm{~s}$ windows around the picked $\mathrm{P}$ and $\mathrm{S}$ wave arrival time. If no picks are available then they are predicted using the 1D location model. We retain all delay times measured from seismograms with a cross-correlation coefficient $(C f)$ of 0.7 or greater, resulting in a total of one million $\mathrm{P}$ and $108,000 \mathrm{~S}$ wave delay times.

[9] Figure 3 shows sample seismograms from five OBSs, aligned on the cross-correlated $\mathrm{P}$ wave train, of 24 strongly correlated events located just east of the axial summit trough (AST). The bottom trace in each panel shows all 24 waveforms superimposed, revealing a wiggle for wiggle match in most cases. Waveform similarities are higher at stations east of the ridge (S001, S002, S007) compared to seismograms recorded on stations west of the ridge (S003, S004) to which the waves traveled through the complex structure associated with rifting and hydrothermal processes beneath the ridge crest. Stations close to the events show clear $\mathrm{P}$ and $\mathrm{S}$ wave energy, while station S009, the most distant station, exhibits the weakest signals (seismograms for S009 not shown in Figure 3). A secondary phase that arrives between the $\mathrm{P}$ and $\mathrm{S}$ wave at stations $\mathrm{S} 002$ and $\mathrm{S} 007$ is interpreted as a $\mathrm{P}$ to $\mathrm{S}$ wave conversion at the boundary of layer $2 \mathrm{~A} / 2 \mathrm{~B}$. At station $\mathrm{S} 002$ the $\mathrm{P}-\mathrm{S}$ conversion trails the $\mathrm{P}$ phase by $\sim 0.2 \mathrm{~s}$ while at S007 it is $\sim 0.4 \mathrm{~s}$, consistent with the thickening of layer $2 \mathrm{~A}$ with increasing distance from the ridge axis. Using a $\mathrm{Vp} / \mathrm{Vs}$ ratio of 4 in layer $2 \mathrm{~A}$ (Figure $2 \mathrm{~b}$ ) we calculate a thickness of $\sim 0.5 \mathrm{~km}$ beneath $\mathrm{S} 007$, consistent with the active source data of Vera et al. [1990]. Stations S002, S004, and S007 all record the bounce from the water surface at about $3.5 \mathrm{~s}$ after the $\mathrm{P}$ wave arrival.

[10] Cross-correlation aligned seismograms as shown in Figure 3 are useful in evaluating the consistency of the analyst picks (shown by red ticks on each seismogram). P wave onset times have been reliably picked for most of the 24 events. The S picks are noisier compared to the $\mathrm{P}$ picks because of the $\mathrm{P}$ wave coda obscuring the $\mathrm{S}$ wave onset. At station S003 the P waves appear to be picked late for shallower events due to a less clear phase onset, and picked correctly for deeper events. It is noteworthy that in the double-difference inversion consistently late (or early) picked phases are less problematic than a mixture of early and late picks. Delay times formed between late and early P picks at station S003, for example, exhibit higher residuals during the double-difference inversions and will therefore be down-weighted or removed. Erroneous but consistent picking of near-surface conversions instead of the direct wave will not significantly 


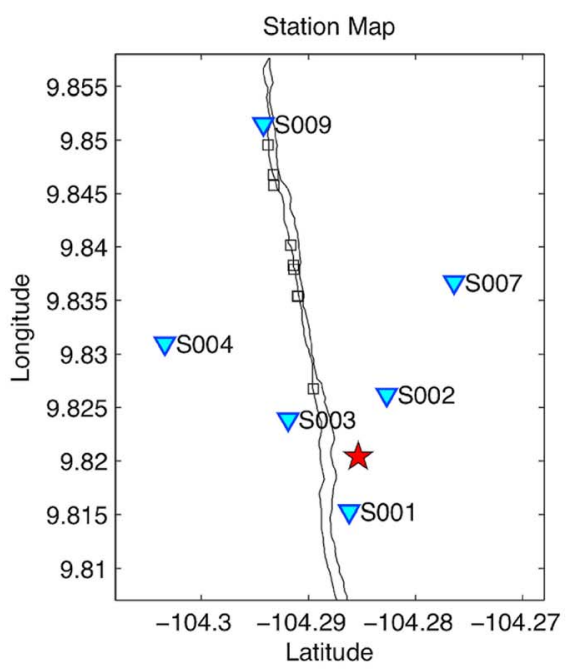

S004

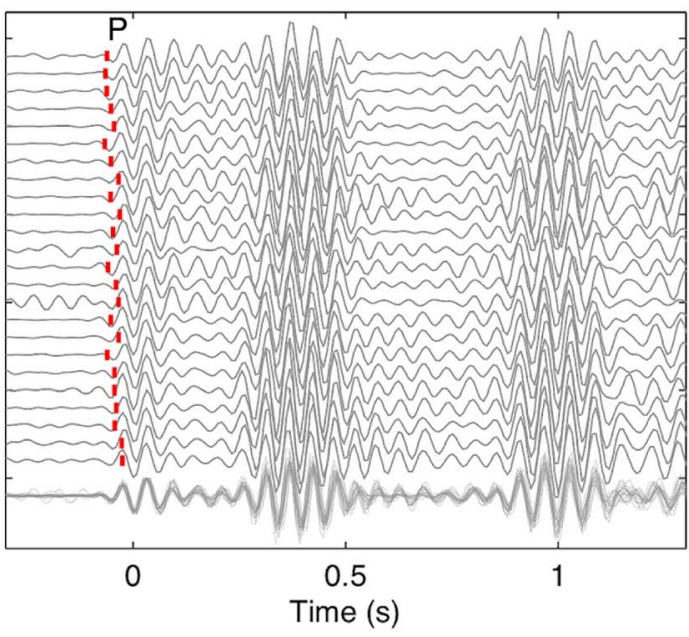

S003

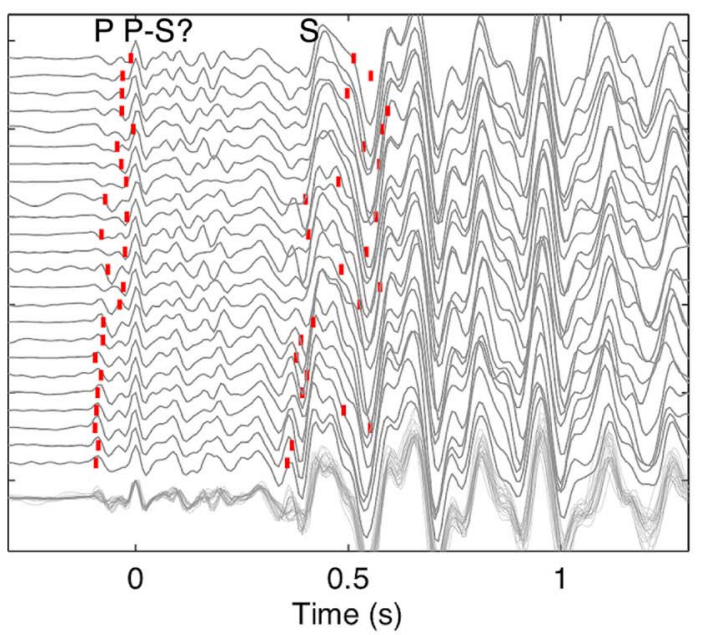

S007

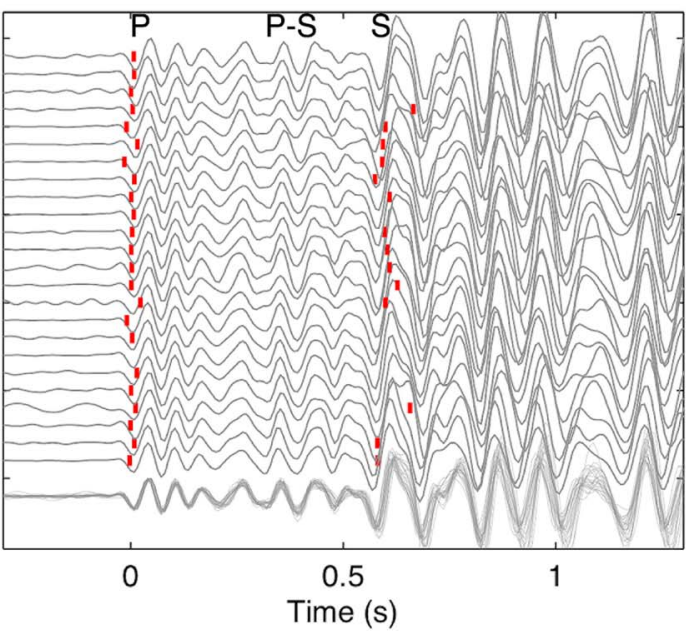

S002

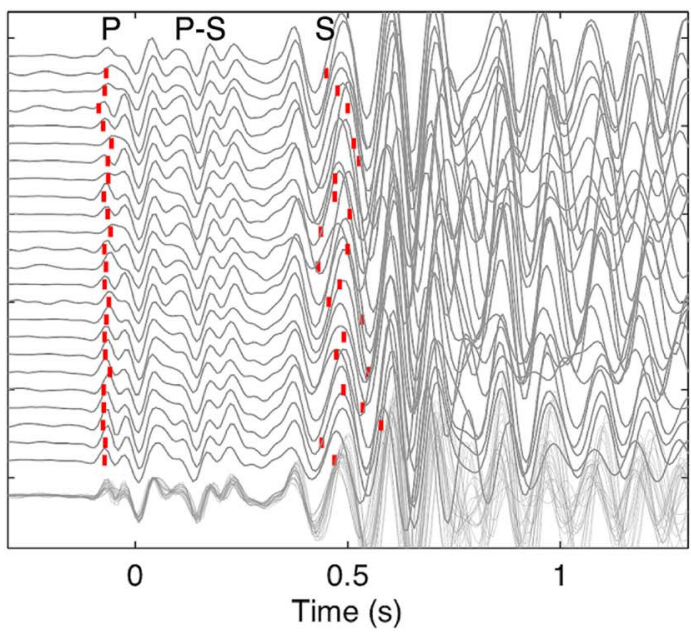

S001

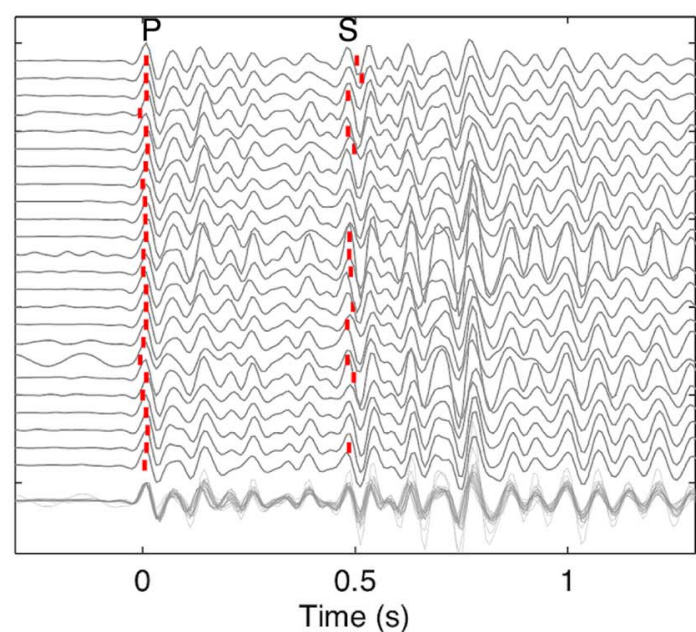

Figure 3. Seismograms of 24 earthquakes aligned on the correlated P wave train, shown for stations S001-S004 and S007. Bottom traces show all seismograms superimposed. Red ticks show analyst $\mathrm{P}$ and $\mathrm{S}$ wave onset picks. Station map shows location of event cluster (red star) and OBS locations (triangles). Thin line denotes AST. 

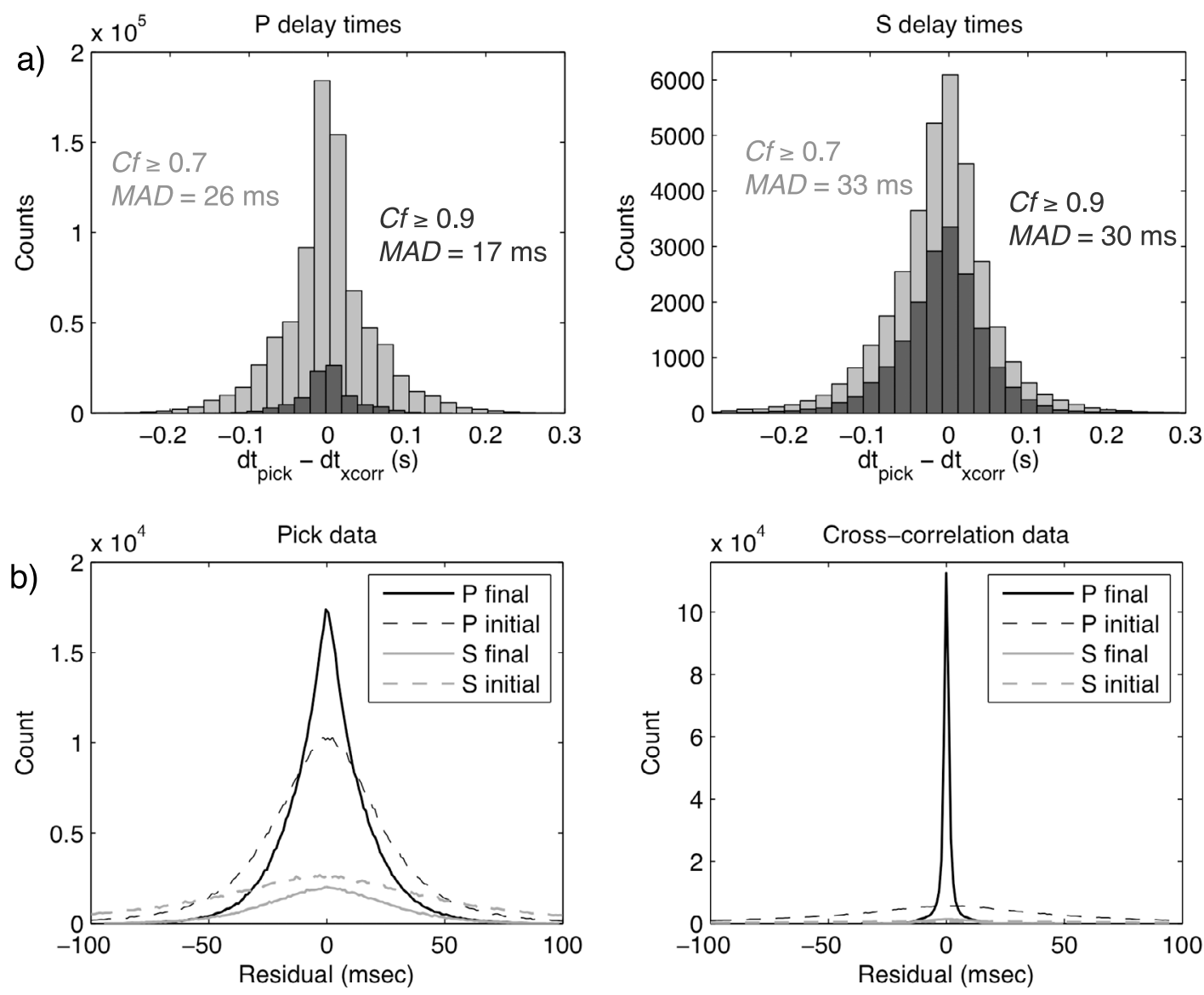

Figure 4. (a) Histograms of differences between pick and cross-correlation $\mathrm{P}$ wave and $\mathrm{S}$ wave delay times for corresponding pairs of events, shown for two correlation coefficient (Cf) cutoff values. MAD, median absolute deviation. (b) Distribution of delay time residuals before and after double-difference relocation, shown for pick and cross-correlation data separately.

bias the double-difference solutions as long as their partial derivatives are similar. This, however, may not be the case for P-S conversions, especially at stations above a thick layer 2A.

[11] The absolute differences between pick and corresponding cross correlation based delay times for $\mathrm{P}$ and $\mathrm{S}$ waves have means generally less than $0.05 \mathrm{~s}$. Absolute median deviations (MAD) are $0.026 \mathrm{~s}$ for $\mathrm{P}$ waves and 0.033 for $\mathrm{S}$ waves for measurements with correlation coefficients $\geq 0.7$ (Figure $4 a$ ). These values mainly represent the (low) uncertainty of the arrival time picks, as the precision of the crosscorrelation data is typically in the range of a few milliseconds. The statistics are similar for data with $C f \geq 0.9$ (MAD $=0.017 \mathrm{~s}$ for $\mathrm{P}$ and $0.030 \mathrm{~s}$ for $\mathrm{S}$ waves) (Figure 4a), indicating that the crosscorrelation measurements are robust down to the $C f$ cutoff value of 0.7 .

\subsection{Hypocenter Relocation}

[12] Pick and cross-correlation delay times are combined and simultaneously inverted for event separation using the double-difference algorithm hypo $D D$, relocating events that do not correlate to the accuracy of the pick data, and those that do correlate to the accuracy of the correlation data. Dynamic iteration-dependent weighting functions are used to account for the different data types and quality and varying event separation and residual performance [Waldhauser and Ellsworth, 2000; Waldhauser, 2001]. After relocation, the RMS of the (unweighted) pick based delay time residuals is $0.015 \mathrm{~s}$ (down from $0.038 \mathrm{~s}$ ), and the RMS of the cross-correlation time residuals is $0.004 \mathrm{~s}$ (Figure $4 \mathrm{~b}$ ). The RMS values are based on $82 \%$ of the original pick and $66 \%$ of the original crosscorrelation delay times used during the final iteration. Most delay times get removed during the 

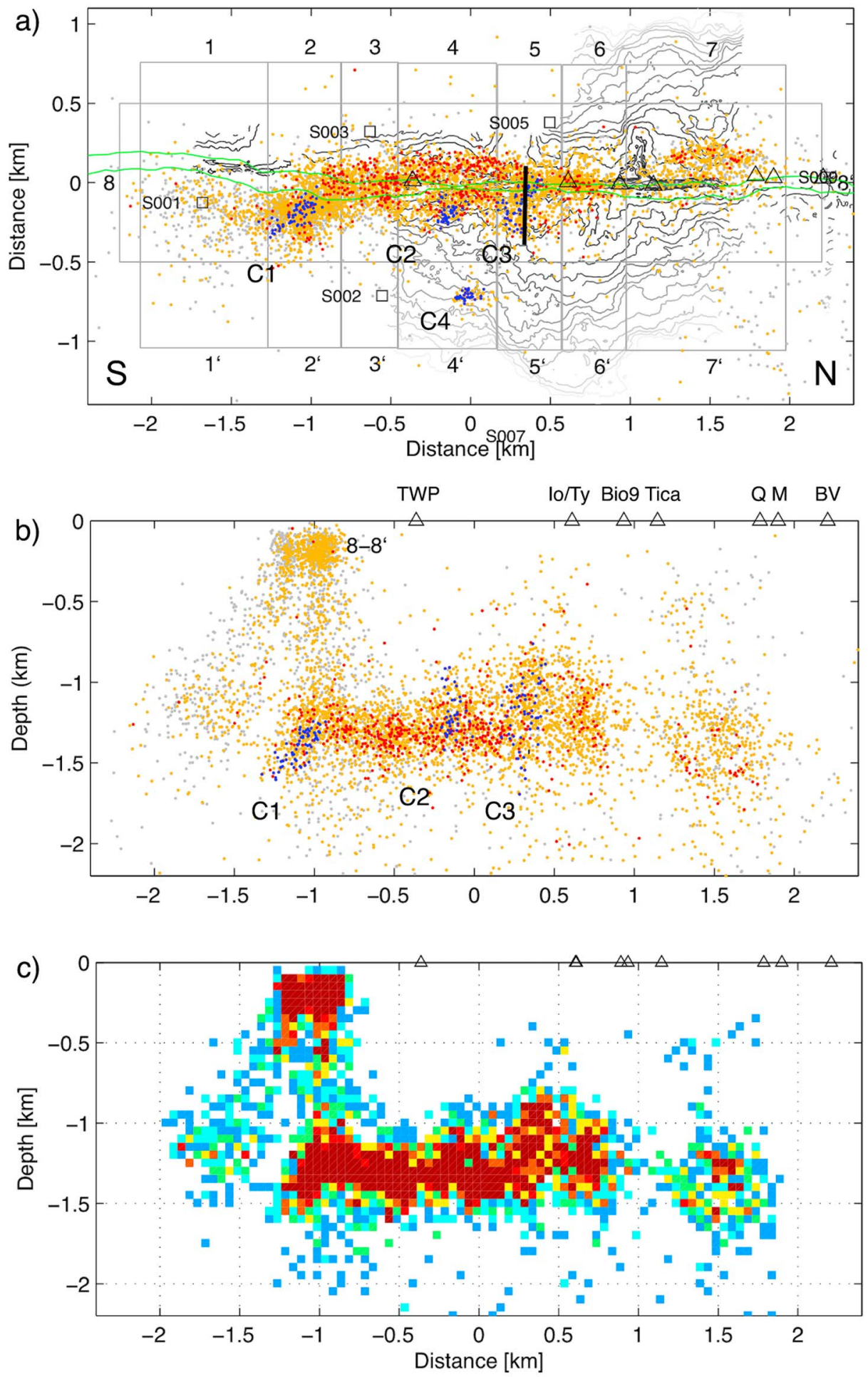

Figure 5. (a) Map view and axis (b) longitudinal and (d) perpendicular cross sections of final locations (dots). Labeled boxes in Figure 5a outline events included in cross sections. Orange dots represent events that correlated at $C f>0.7$, and red dots represent events that correlated at $C f>0.9$. Groups of blue dots labeled $\mathrm{C} 1-\mathrm{C} 4$ are strongly correlated events. (c) On-fault view of event density (red $>10$ events). In Figure 5a labeled squares denote station locations, green lines are mapped AST, gray lines are bathymetry contours [Ferrini et al., 2007], and thick black line is location of imaged AMC [Kent et al., 1993]. In Figure 5d gray lines on top of each cross section denotes ridge topography where available (vertical exaggeration is 15). Triangles are high-temperature vent locations (TWP, Tube Worm Pillar; BV, Bio Vent). Arrows point to steeply dipping faults discussed in text. 

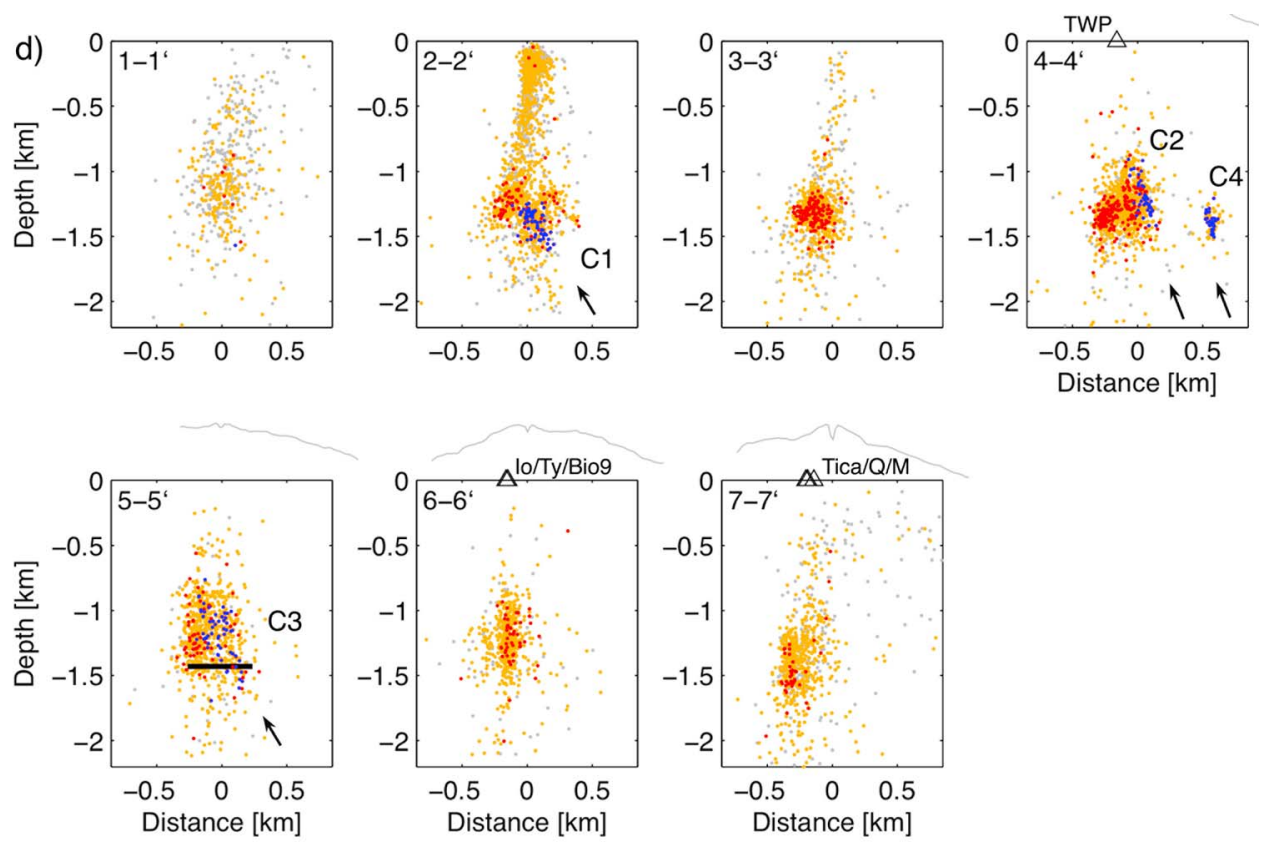

Figure 5. (continued)

final double-difference iterations by the distance weighting function [Waldhauser and Ellsworth, 2000] that retains, in this specific study, delay times only for pairs of hypocenters that are less than a few hundred meters apart. Relative location uncertainties are computed from a bootstrap analysis of the final residual vector. Horizontal and vertical projection of the $95 \%$ confidence ellipses derived from 200 bootstrap samples are on average $45 \mathrm{~m}$ and $52 \mathrm{~m}$, respectively. Formal uncertainty estimates of the absolute locations of individual events are somewhat larger, but the overall location of the seismicity pattern is well constrained by its strong correlation with geologic surface features [Tolstoy et al., 2008]. Several tests confirm both precision and accuracy of the double-difference locations and demonstrate that the seismicity pattern we image is robust (Appendix A).

\section{Results}

\subsection{Locations}

[13] The final 7,300 hypocenter locations are presented in Figure 5 in map view and depth sections along and across the ridge axis. A 3D rendition of the seismicity distribution is given in Figure 6. These surfaces drape over volumes of dense seis- micity. Most of the recorded seismic activity concentrates along a $\sim 4 \mathrm{~km}$ long stretch of ridge axis and within a few hundred meters of the AST, with an apparent aseismic gap of a few hundred meter length observed in the northern part of the array (Figure 5a). While the seismicity west of the AST gently bulges westward in the central part of the array, the seismicity east of the AST exhibits a rougher boundary between seismic and aseismic areas (Figures 5a and 6). Depth sections of hypocenter locations (Figures $5 \mathrm{~b}$ and $5 \mathrm{~d}$ ) and density distribution (Figure 5c) reveal that the majority of earthquakes locate in two areas: in a horizontal zone between 1.1 and $1.5 \mathrm{~km}$ depth and a dense cluster reaching a few hundred meters below the surface near the southern end of the array (Figure 6). Two near vertical pipe like structures of activity are seen leaving the near surface cluster; one connecting to the horizontal seismicity zone at $1.1 \mathrm{~km}$ depth (Figure $5 \mathrm{~d}$, cross section 2-2'), the other veering to the south. Both pipes veer slightly to the west, with the one veering to the south including fewer recorded earthquakes presumably due to its location at the southern edge of the OBS array. Compared to the pick-based DD solutions presented by Tolstoy et al. [2008], the new locations show sharper structures associated with the pipes and a narrower seismicity band, and resolve an asymmetry in the 
a)

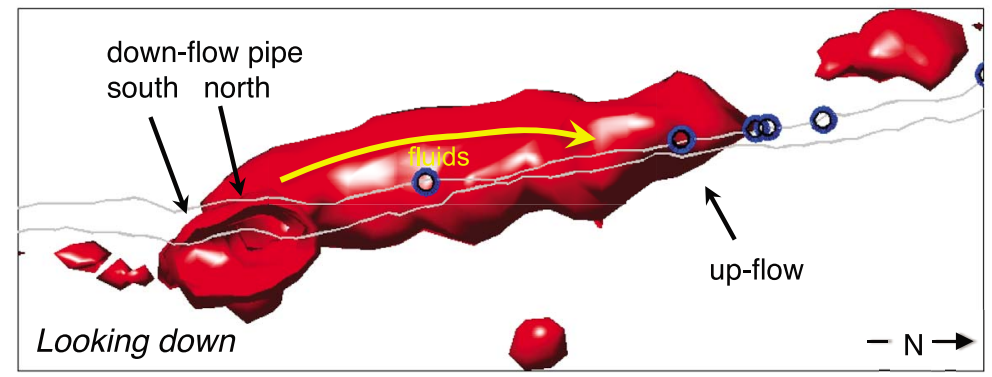

b)

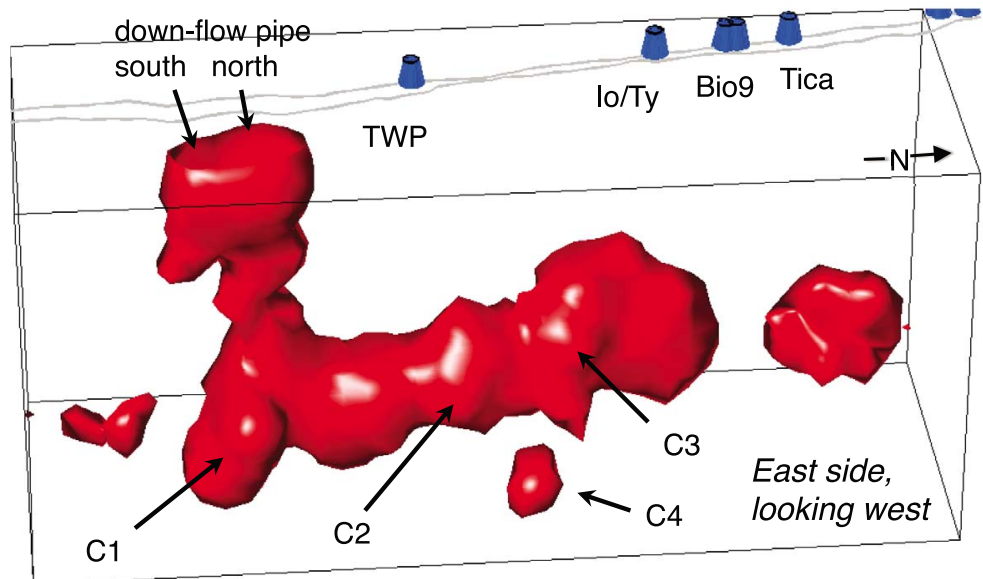

c)

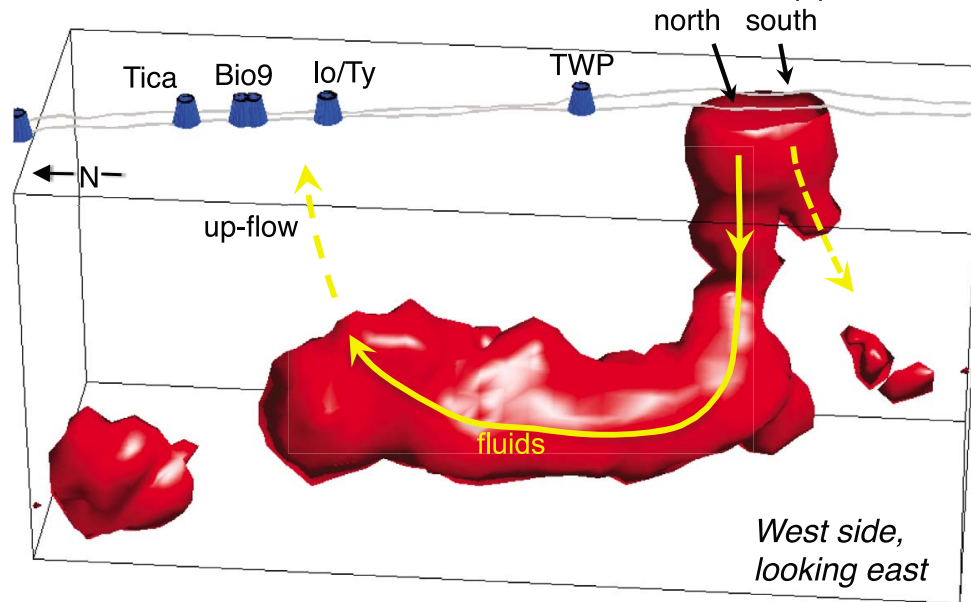

Figure 6. Three-dimensional renditions of the seismicity. (a) Map view, (b) looking WNW, and (c) looking ENE. Gray lines denote mapped AST, blue cones denote high-temperature vents, and yellow arrows indicate path and direction of inferred fluid flow.

epicenter distribution. The improvements are greatest with respect to depths due to the additional $\mathrm{S}$ wave correlation data.

\subsection{Correlation Characteristics}

[14] About $75 \%$ of the relocated events consist of event pairs that share similar waveforms with $C f \geq$ 0.7 at a minimum of 2 stations (orange dots in Figures $5 \mathrm{a}, 5 \mathrm{~b}$, and $5 \mathrm{~d}$ ). The locations of the correlated events coincide, to a first order, with the two areas of high event density at the top of the vertical pipe and within the deeper horizontal seismicity zone. The most strongly correlated events $(C f \geq$ 0.9 at 3 or more stations, red dots) cluster predominantly within the horizontal seismicity zone. Waveform similarity typically decays with increasing event separation as a result of increasing paths and source variation. Figure 7 shows both the distribution of $C f$ values and the number of correlated pairs as a function of hypocenter separation. Compared to events within the vertical pipe, events in the 

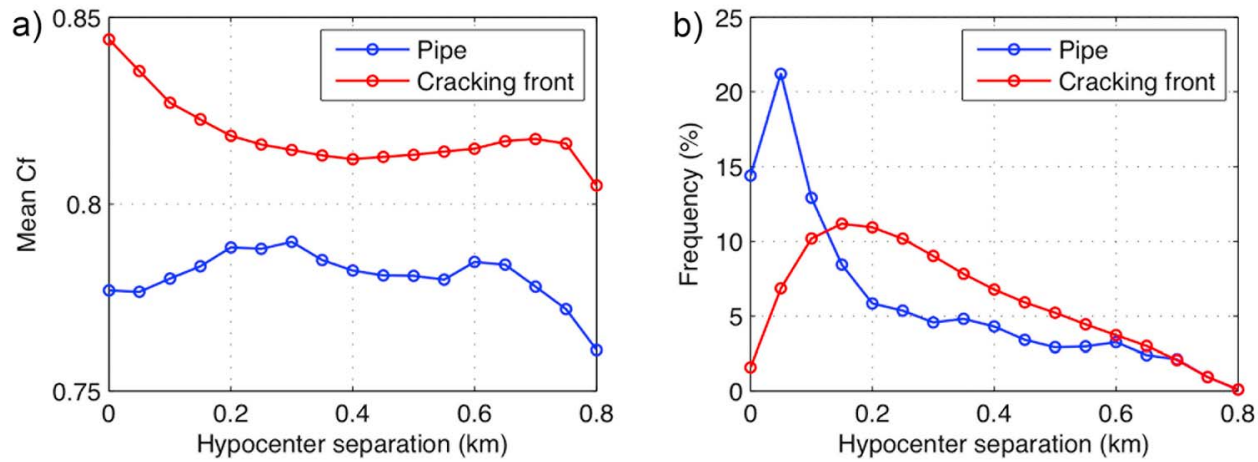

Figure 7. (a) Mean correlation coefficients (Cf) and (b) percentage of correlated events as a function of hypocenter separation, shown separately for correlated events in the down-flow pipe (depths $<1 \mathrm{~km}$ ) and in the horizontal seismicity zone (depths $>1 \mathrm{~km}$ ). Means are calculated within bins of $50 \mathrm{~m}$ separation distances.

horizontal tube correlate over longer distances with higher correlation coefficients (Figure 7).

[15] Earthquakes along the rough eastern wall of the horizontal seismicity zone, in particular the correlated events, occur predominantly on narrow, steeply east dipping, NNW trending structures that are about $0.5 \mathrm{~km}$ tall and reach depths of $1.5 \mathrm{~km}$ (Figures $5 \mathrm{a}$ and $5 \mathrm{~d}$ ). Some of the most strongly correlated events, indicated by blue dots in Figures $5 \mathrm{a}$, $5 \mathrm{~b}$, and $5 \mathrm{~d}$, are included in three of these structures labeled $\mathrm{C} 1-\mathrm{C} 3$. Events within these clusters are characterized by waveforms that are remarkably similar from the onset of the $\mathrm{P}$ wave through the $\mathrm{S}$ phase and the coda (see Figure 3 for seismograms of events in $\mathrm{C} 1$ ). Cluster $\mathrm{C} 1$, which locates at the base of the vertical pipe, includes some of the deepest events. Clusters $\mathrm{C} 2$ and $\mathrm{C} 3$ are somewhat shallower (starting at $1.4-1.5 \mathrm{~km}$ depth) and locate in the central part of the array. A fourth cluster of strongly correlated earthquakes, $\mathrm{C} 4$, that ruptured a simple, clearly defined structure is located about $700 \mathrm{~m}$ east of the AST around $9.83 \mathrm{~N}$ at depths between 1.2 and $1.5 \mathrm{~km}$ (Figure 5). It is the only significant off-axis activity within the array we observed during the 6 months observational period. In contrast to the repeated slip observed in $\mathrm{C} 1-\mathrm{C} 3$ above the AMC, where events occurred over the 6 months observational period, most events $(\sim 80)$ that form structure $\mathrm{C} 4$ occurred within a $12 \mathrm{~h}$ period on February 27/28. The largest event had a magnitude $\mathrm{M}_{\mathrm{L}}=0.2$ and occurred $7 \mathrm{~min}$ after the activity begun, indicating that the events might represent a foreshock-mainshock-aftershock sequence.

\subsection{Focal Mechanisms}

[16] The limited distribution and quality of first motion data hampers the computation of focal mechanisms for most events. For the strongly correlated events in $\mathrm{C} 1-\mathrm{C} 4$, however, we derived composite solutions by stacking the first motion polarities for the most impulsive events (Figure 8). Because of the limited availability of data we could not estimate the active fault planes in a formal way. Instead, we manually estimated a range for planes, assuming double-couple sources, which fit both the polarity data and the general strike of the active faults $\mathrm{C} 1-\mathrm{C} 4$ as imaged by the relocated seismicity (see cross sections 2, 4, and 5 in Figure 5d). The resulting focal mechanisms indicate reverse faulting on eastward dipping faults that strike parallel to the ridge axis (Figure 8). An oblique slip component appears to be present in the mechanisms of the offaxis events in $\mathrm{C} 4$.

\section{Discussion}

\subsection{Seismogenic Processes}

[17] The overall structure of the improved relocations is consistent with the general features observed by Tolstoy et al. [2008] where we interpreted them as the seismic expression of an along axis hydrothermal circulation cell: a narrow down-flow zone near a 4th order axial discontinuity expressed by seismicity along the pipe like structure between the surface and $1.5 \mathrm{~km}$ depth at $9.82^{\circ} \mathrm{N}(-1 \mathrm{~km}$ model distance in Figures 5a and 5b); a seismically less pronounced and more broadly defined up-flow zone at around $9.84^{\circ} \mathrm{N}$ presumably feeding the overlying active high-temperature vents Io, Bio9, and Tica; and an approximately $400 \mathrm{~m}$ wide band of seismicity connecting the down- and up-flow zones and overlying the axial magma chamber (AMC) at about $1.5 \mathrm{~km}$ depth [Kent et al., 1993]. A second inferred down-flow pipe is imaged just south of the first one, 


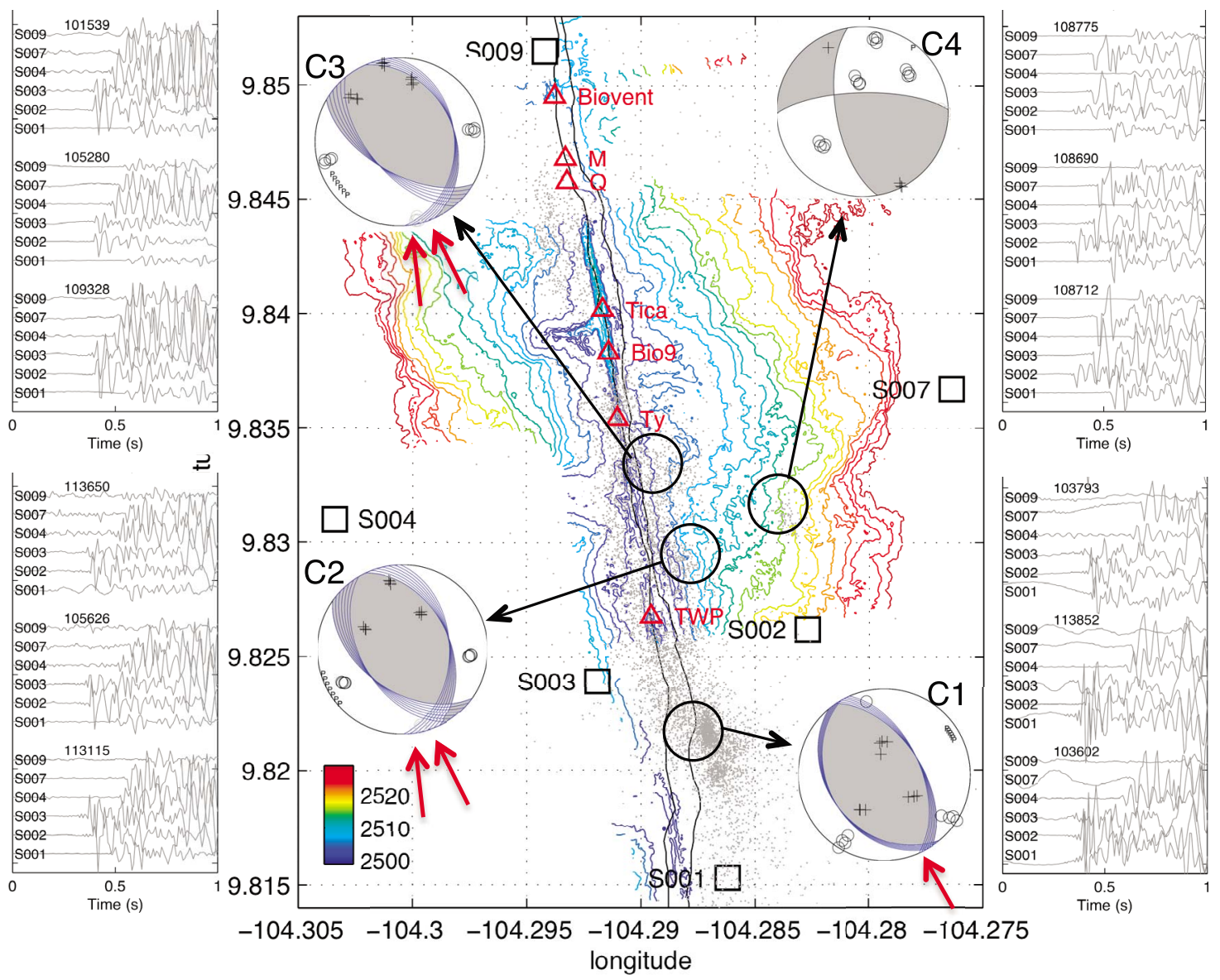

Figure 8. Composite focal mechanisms (lower hemisphere projections) for events in the clusters $\mathrm{C} 1-\mathrm{C} 4$, derived from first motion polarity analysis. Blue lines show range of fault planes that fit both the polarity data and the general orientation of the fault as imaged by the hypocenters, and red arrows indicate strike of end-members for eastward dipping faults. Black circles enclose events used to determine the focal mechanisms, squares are OBS locations, triangles are vent locations, gray lines are AST trace, and contours denote the bathymetry data of Ferrini et al. [2007]. $\mathrm{P}$ wave onsets for three selected events in each cluster are also shown.

veering to the south and presumably feeding an adjacent circulation cell located outside our seismic network with fluids flowing along axis from north to south (Figure $5 \mathrm{~b}$, between -2 and $-1 \mathrm{~km}$ model distance; Figure 6). Most of the earthquakes concentrate within the uppermost $300 \mathrm{~m}$ of the pipe and within the horizontal seismicity zone overlying the AMC (Figure 5c).

[18] Earthquake hypocenters in the inferred downflow zone image two slightly west veering pipes that are interpreted as feeding the central and southern circulation cell, respectively (Figures $5 \mathrm{~b}$ and $5 \mathrm{~d}$, cross section 2-2', and Figure 6). Regional tectonic stresses responsible for the adjoining kink in the AST may have weakened the crust in that area and created a zone of high permeability, providing pathways for fluids to enter the oceanic crust
[Tolstoy et al., 2008]. The fluids may lower the frictional strength of the tectonically stressed faults, causing seismic failure. The change in the density of earthquakes in the down-flow zone at $\sim 0.25 \mathrm{~km}$ depth (Figure 5c) coincides roughly with the layer $2 \mathrm{~A} / 2 \mathrm{~B}$ boundary, suggesting a brittle and highly fractured layer 2A near the AST kink. This is also expressed by the low correlation coefficients that we compute even for events that locate close in space (Figure 7a).

[19] Earthquakes below $0.25 \mathrm{~km}$ in the pipe (Figure 5c) may be caused by crustal-scale thermal strain due to the steep temperature gradient between the seafloor $\left(\sim 2^{\circ} \mathrm{C}\right)$ and the top of the melt lens at $\sim 1.4 \mathrm{~km}$ depth $\left(1100^{\circ}-1200^{\circ} \mathrm{C}\right)$. The tectonic stresses are likely to keep the fluid pathways open via fracturing and prevent them from clogging up 
[Lowell and Yao, 2002], which is supported by high permeabilities $\left(\sim 10^{-9.4} \mathrm{~m}^{2}\right)$ inferred in this zone from modeling of tidal triggering [Crone et al., 2011]. Furthermore, the tidal modulation of these earthquakes [Stroup et al., 2009] suggests that fluid pressures are large enough to maintain a critically stressed fault system. With increasing depths along the pipe, stresses due to an inflating magma chamber may become an increasingly important cause of seismic failure.

[20] The axis perpendicular cross section along 2-2' (Figure 5d) reveals that the west veering down-flow pipe connects to the smooth western side of the horizontal seismicity zone at a depth of $\sim 1.2 \mathrm{~km}$. It suggests that fluids move north toward the up-flow zone mainly along the western side of the horizontal seismicity zone, as seismicity there is diffuse and presumably caused by hydro fracturing above the AMC (Figure 5). Seismic failure along the rough eastern wall of the horizontal seismicity zone is controlled by slip on preexisting, steeply east dipping reverse faults (Figure 8). The existence of reverse faulting in an extensional environment is surprising, as normal faults typically accommodate the stresses associated with tectonic extension. Here, they likely accommodate stresses implied by a inflating magma chamber at the beginning of an eruptive cycle that culminated in January 2006 [Tolstoy et al., 2006]. Fluids that may seep through from the fluid pathways along the western wall of the horizontal seismicity zone might bring these faults closer to failure. Bands of axis-parallel reverse faulting events on the Juan de Fuca ridge have been interpreted to be associated with recharge of magma into the crustal magma chamber [Wilcock et al., 2009]. It is interesting to note that the reverse fault $\mathrm{C} 1$ includes some of the deepest events (Figure 5d, cross section $2-2^{\prime}$ ). It also locates directly beneath the down-flow pipe, suggesting that the cold water may push the thermal boundary and thus the brittleductile transition to greater depths.

[21] The eastern and western strand of the horizontal seismicity zone merge beneath the hightemperature vent pair Io/Ty to form a simple, $\sim 200 \mathrm{~m}$ wide, near vertical and ridge parallel structure that we interpret as the upflow zone (Figure 5d, cross section 6-6'). The lower seismicity rate in the upflow zone compared to the downflow zone may be partly due to the less dense station coverage in the northern part of the central circulation cell. North of the central circulation cell an inferred northern circulation cell appears to be diverging into an asymmetric distribution similar to the central cell (cross section 7-7').

[22] The axis-perpendicular cross sections in Figure $5 \mathrm{~d}$ indicate a change from an arrow shaped base of the seismogenic layer beneath the downflow pipe to a horizontal cutoff of seismicity near the inferred up-flow zone at $\sim 1.4 \mathrm{~km}$ depth. It is possible that these changes reflect variations in the expression of the underlying magma sill. A narrow sill may be present in the southern part of the circulation cell (cross sections 2-2' and 4-4'), with the sharp, near vertical structures that define faults $\mathrm{C} 1$ and $\mathrm{C} 2$ representing brittle asperities on the eastern wall of such a sill. A wider sill may have formed near C3 (cross section 5-5'). Both depth and lateral extent of the deepest seismicity near $\mathrm{C} 3$ correlates with the location and extent of a melt lens that was imaged by active source data [Kent et al., 1993] (Figure 5d, cross section 5-5'). It is important to note that the melt lens was imaged in 1985, and the general structure of the system therefore appears robust over extended periods of times, or at least between periods of eruptive activity. Projection of the $\mathrm{C} 3$ structure to the surface coincides with the location of two active hydrothermal vents, Io and Ty (Figure 5), suggesting that C3 may represent a main upflow path. This is supported by an upward bulging of the seismicity in the $\mathrm{C} 3$ area that is best seen in Figure 6.

[23] Only one noteworthy cluster of seismic activity occurred off-axis and within the OBS array during the 6 months observational period. It includes events along $\mathrm{C} 4$ that ruptured a simple, clearly defined structure about $700 \mathrm{~m}$ east of the AST around $9.83 \mathrm{~N}$ at depths between 1.2 and $1.5 \mathrm{~km}$ (Figure 5). The range of possible composite focal mechanisms that fit both the polarity and the hypocenter data include slip on a ridge parallel, oblique reverse fault (Figure 8). Because $\mathrm{C} 4$ is similar in orientation and spatial extension to $\mathrm{C} 2$ (Figure 5d, cross section 4-4'), we speculate that the swarm on C4 reactivated an old fault that was formed beneath the ridge axis about 4000 years ago (assuming a constant spreading rate of $11 \mathrm{~cm} /$ year [Carbotte and Macdonald, 1992]) and migrated east as new oceanic crust was formed. This is supported by the observation that fault $\mathrm{C} 4$ is located slightly deeper than $\mathrm{C} 2$, which may reflect the effect of thickening Layer 2A with increasing age or distance from the ridge axis.

[24] Although the tidal stresses at $9^{\circ} 50^{\prime} \mathrm{N}$ are small $(<2 \mathrm{kPa})$, seismic slip along $\mathrm{C} 1-\mathrm{C} 4$ predominately 


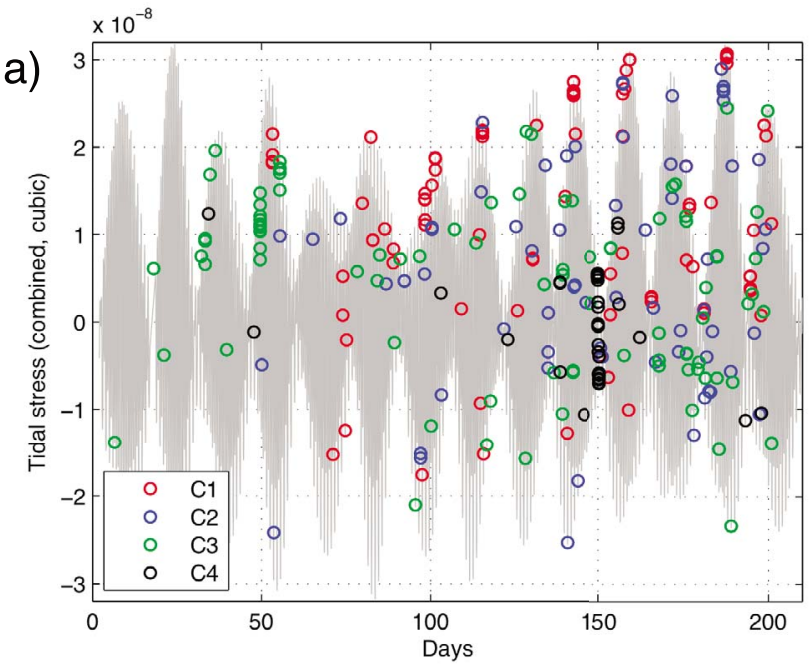

b)
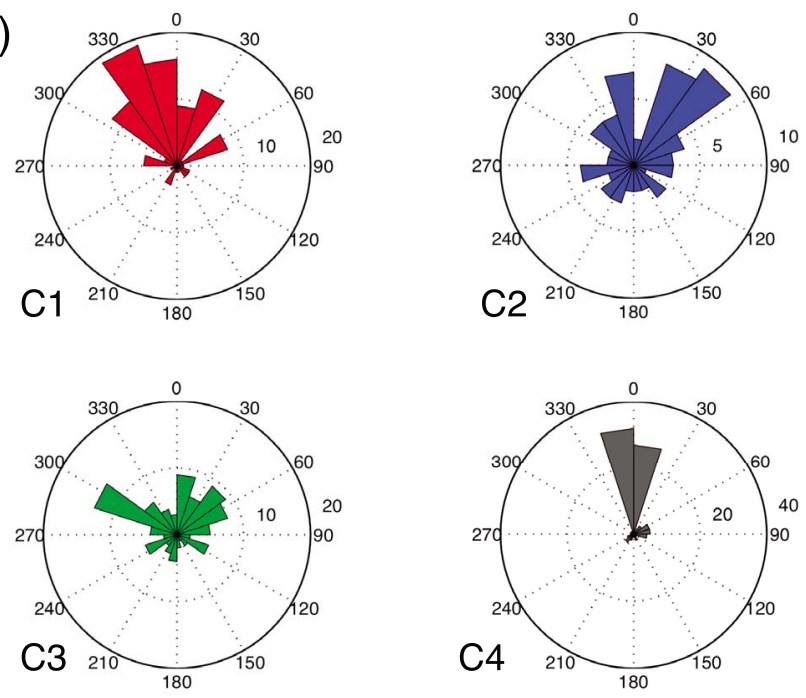

Figure 9. (a) Combined ocean tidal loading and Earth tide stresses at $9^{\circ} 50^{\prime} \mathrm{N}$ for the 220 day observational period (October 2003 to April 2004). Superimposed are earthquakes color coded by their association with clusters C1-C4. Positive values of stress indicate extension. (b) Rose diagrams showing the phase distribution of microearthquakes relative to the combined OTL and Earth tide. Definition of tidal phase angle same as in the work by Tanaka et al. [2002]: The maximum and the minimum of the tidal stress just before or after each earthquake are assigned to 0 and \pm 180 , respectively, and the tidal phase angle is defined by linearly dividing the time interval between them.

occurs near times of peak extension when the confining compressing stresses are at a minimum (Figure 9), indicating that these fracture systems are critically stressed [Stroup et al., 2007]. Furthermore, increased permeability may allow fluids to enter the fault zones more easily and lower the frictional strength of the faults. Another possibility is that the faults respond to AMC inflation that is modulated by the earth tides. Earthquakes along $\mathrm{C} 1$ at the bottom of the downflow pipe are triggered preceding the maximum predicted volumetric extension, while the earthquakes along $\mathrm{C} 2$ directly above the AMC are triggered after the maximum of predicted volumetric extension (Figure $9 \mathrm{~b}$ ). This is consistent with Stroup et al. [2009] who find systematic clockwise rotation of phase angles relative to peak extension along the ridge axis. Events along $\mathrm{C} 1$ preferentially occur during spring tides (Figure 9a), suggesting that this fault is stronger and/or the permeability is lower compared to $\mathrm{C} 2$ and $\mathrm{C} 3$.

\subsection{Regional Kinematics}

[25] The strike of the $\mathrm{C} 1$ structure exhibits a small but resolvable counterclockwise skew relative to the 
NNW direction of the ridge axis north of the kink (Figure 8). The skew can be seen in both the fault structure as imaged by the hypocenters along $\mathrm{C} 1$ as well as the composite focal mechanism. We argue that the skew is caused by differential tectonic stresses that are also responsible for the kink in the overlying surface expression of the ridge axis. The kink marks a change in axis orientation from N-S south of the kink to NNW-SSE north of it. It is possible that it takes up the differential stresses that arise from extensional plate motion $(11 \mathrm{~cm} /$ year $)$ in direction perpendicular to the ridge axis and the absolute plate motion $(35 \mathrm{~cm} /$ year) in northwest direction. Thus, it is possible that some basal drag process is playing a role in generating the skew observed for the $\mathrm{C} 1$ structure. Due to the limited data coverage focal mechanisms of the events along $\mathrm{C} 2$ and $\mathrm{C} 3$ allow for a range of strikes that include ridge parallel to a slight counterclockwise skew similar to the $\mathrm{C} 1$ structure (Figure 8).

[26] Recent results from analysis of active source seismics in the $9^{\circ}-10^{\circ} \mathrm{N}$ EPR area have inferred an anticlockwise skew of $\sim 10^{\circ}$ in the alignment of mantle upwelling from the normal of the ridge axis [Toomey et al., 2007]. While this interpretation has been controversial [Singh and Macdonald, 2009; Toomey et al., 2009], the near alignment of the skew of the compressional focal mechanisms $\left(\sim 15^{\circ}\right.$ anticlockwise) with the skew inferred in the mantle is notable, and also consistent with Nuvel 1-A plate spreading direction for the area [Gripp and Gordon, 2002]. Toomey et al. [2009] suggest that the skew is a driving force for changes in plate boundary kinematics, with basal tractions imposed by mantle flow contributing to ongoing anticlockwise changes in plate spreading directions. While the skew in orientation of our C2 and C3 focal mechanisms are not well constrained, the results observed, if sustained through later deployments, would be consistent with Toomey et al.'s model, despite the general assumption that melt lens dynamics are decoupled from mantle melt supply [Combier et al., 2008]. However, the Combier et al. results are from the structurally more complex overlapping spreading center (OSC) at $9^{\circ} \mathrm{N}$ where local stresses from the OSC may dominate upper crustal tectonics more than would occur at $9^{\circ} 50^{\prime} \mathrm{N}$. At $9^{\circ} 50^{\prime} \mathrm{N}$ regional stresses from plate separation may be the primary control, in particular the (progressively anticlockwise) reorganization of plate motion over the last few million years [Pockalny et al., 1997]. Results from 3-D multichannel seismic work indicate that the axial magma chamber in the $9^{\circ} 50^{\prime} \mathrm{N}$ area is highly segmented, with some segments showing evidence for slight anticlockwise rotation, and others not (S. Carbotte, personal communication, 2011).

\section{Conclusions}

[27] We have applied high-precision waveform cross-correlation based double-difference location methods to 7,300 earthquakes recorded between October 2003 and April 2004 by a dense OBS array located on the East Pacific Rise at $9^{\circ} 50^{\prime} \mathrm{N}$. The new relocations confirm the overall description of an along axis hydrothermal circulation cell reported by Tolstoy et al. [2008], and provide new insight into the tectonic, magmatic, and hydrothermal processes that accompany the precursory phase of a magmatic spreading event and seismic crisis in January 2006. We locate a zone of intense cracking just below the ocean floor near a 4th order axial discontinuity where water is inferred to be entrained into the down-flow pipe and slip is likely caused by local tectonic stresses. High-precision relocations and composite focal mechanisms reveal steeply dipping reverse faults that overly the AMC. They define the eastern wall of a horizontal zone of intense seismicity and are likely activated by AMC inflation and possibly injection of magma into a narrow sill. At least one reverse fault exhibits a resolvable anticlockwise skew in its strike relative to the direction of the ridge axis, suggesting that the regional tectonic stress field or mantle dynamics may be controlling the seismogenic faults at depth. The limited number of stations prevents us from resolving such detailed structural and kinematic information for other faults. Data from subsequent deployments recorded at this site, when processed and located, should better constrain the consistency and orientation of fault structures in the upper crust and their driving stresses, if they are robust throughout the eruption preparation.

\section{Appendix A: Evaluation of Data and Location Robustness}

[28] Sparse station coverage and the small magnitudes of recorded events are offset by a high event density that can be harnessed with the doubledifference method and the quality of our handpicked arrival time picks. We perform a few simple tests, described in more detail by Waldhauser and Ellsworth [2000], aimed at quantifying the robustness of our double-difference solutions. A first test 
a) True Locations

b) Initial Locations

c)DD Relocation, 3 STA d)DD Relocation, 4 STA
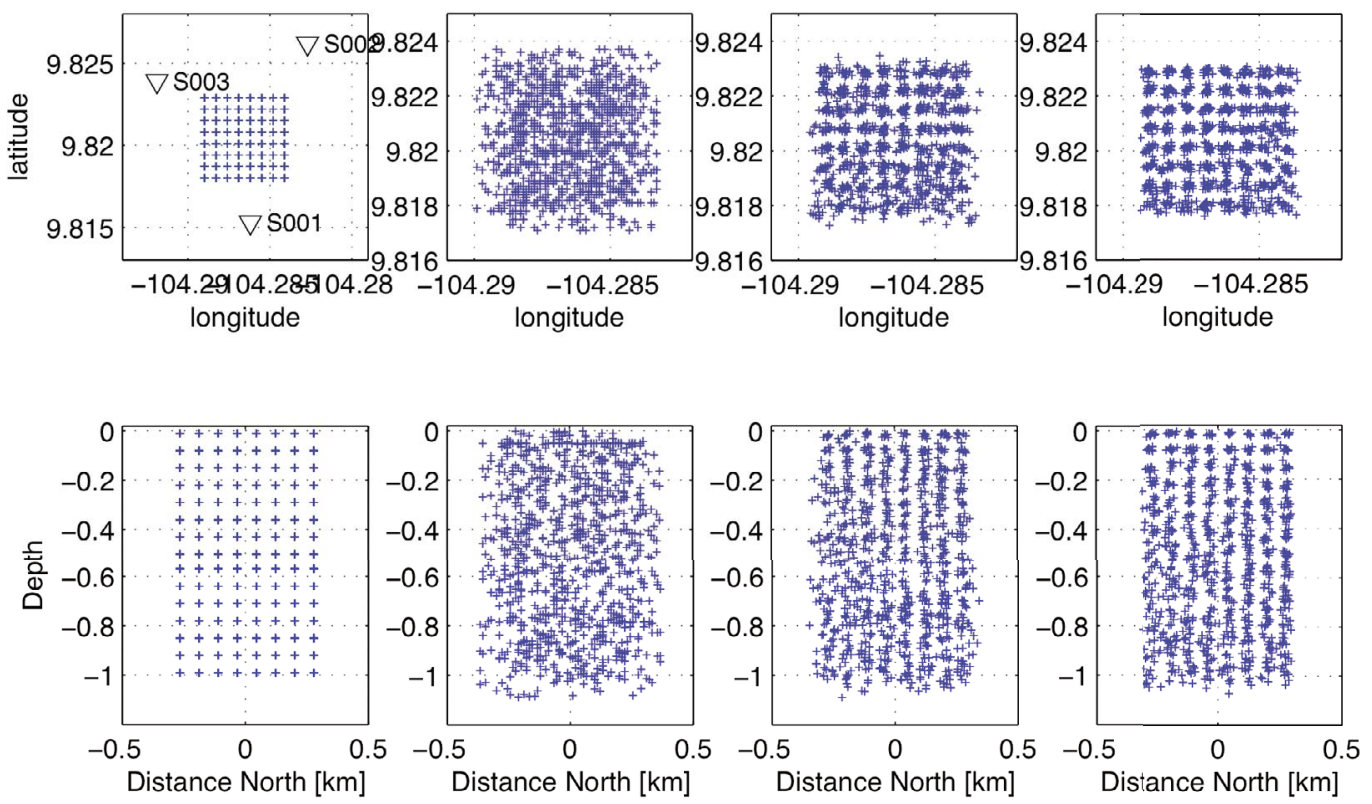

Figure A1. Testing robustness of source location in down-flow pipe using synthetic P and S wave travel times computed from 960 synthetic sources (pluses) representing a pipe like structure to the nearest OBSs S001-S003 (triangles). (top) Map views and (bottom) depth sections. (a) Locations used to compute the travel times. (b) Locations used as starting values. (c) DD relocations using stations S001-S003. (d) DD relocations using the four nearest stations.

aims at evaluating the robustness of the shallow events in the down-flow zone. Depths of shallow sources are typically difficult to resolve as the partial derivatives are approaching zero, especially when the stations are close by. In order to test the robustness of the shallowest earthquake locations in the down-flow zone, we conducted a synthetic test. We compute synthetic $\mathrm{P}$ and $\mathrm{S}$ travel times from 960 sources, simulating the pipe like structure imaged in our relocated seismicity, to the 3 nearest stations S001, S002, and S003 (Figure A1a). We add noise with a standard deviation of $0.01 \mathrm{~s}$ to the synthetic differential times and location errors with a standard deviation of $100 \mathrm{~m}$ to the initial (true) locations (Figure A1b), and relocated these data using hypoDD. The results (Figure A1c) show that we are able to reconstruct the pattern of the true locations throughout the pipe, with mislocations ranging from several meters for events in the center of the pipe where connectivity is highest, to tens of meters at the pipe's periphery. If we add the fourth closest station to the synthetic data set, then the double-difference algorithm is able to restore the pattern out to the pipe's periphery (Figure A1d).

[29] A second test is aimed at evaluating the consistency and accuracy of the arrival time picks for
$\mathrm{P}$ and $\mathrm{S}$ phases (Figure A2). We select 22 events that spread across a significant part of the seismicity and are well connected through both $\mathrm{P}$ and $\mathrm{S}$ wave pick differential times so that they can be relocated as a single cluster with $\mathrm{P}$ and $\mathrm{S}$ phase data individually. The starting locations are chosen to be a common location at the centroid of the cluster (indicated by a blue star in Figure A2). Figure A2a shows the DD solutions for the $\mathrm{P}$ phase data, Figure $\mathrm{A} 2 \mathrm{~b}$ for the $\mathrm{S}$ phase data, and Figure $\mathrm{A} 2 \mathrm{c}$ for the combined $\mathrm{P}$ and $\mathrm{S}$ data. In all three cases the same pattern of seismicity is revealed, demonstrating the high quality and consistency of the manually picked arrival times. Note that fewer events could be relocated using the S pick differential times alone, since we typically have fewer and noisier S picks (which is also expressed in the larger crosses that represent the least squares errors).

[30] Finally, we test the sensitivity of the differential time data to the absolute location of the events. We use the same 22 earthquakes from the previous test, with original locations taken from the final DD catalog computed in this study and shown again in map view and N-S cross section in Figure A3a. We move the entire cluster $1 \mathrm{~km}$ to the south and $0.4 \mathrm{~km}$ shallower relative to its original location, simulating 

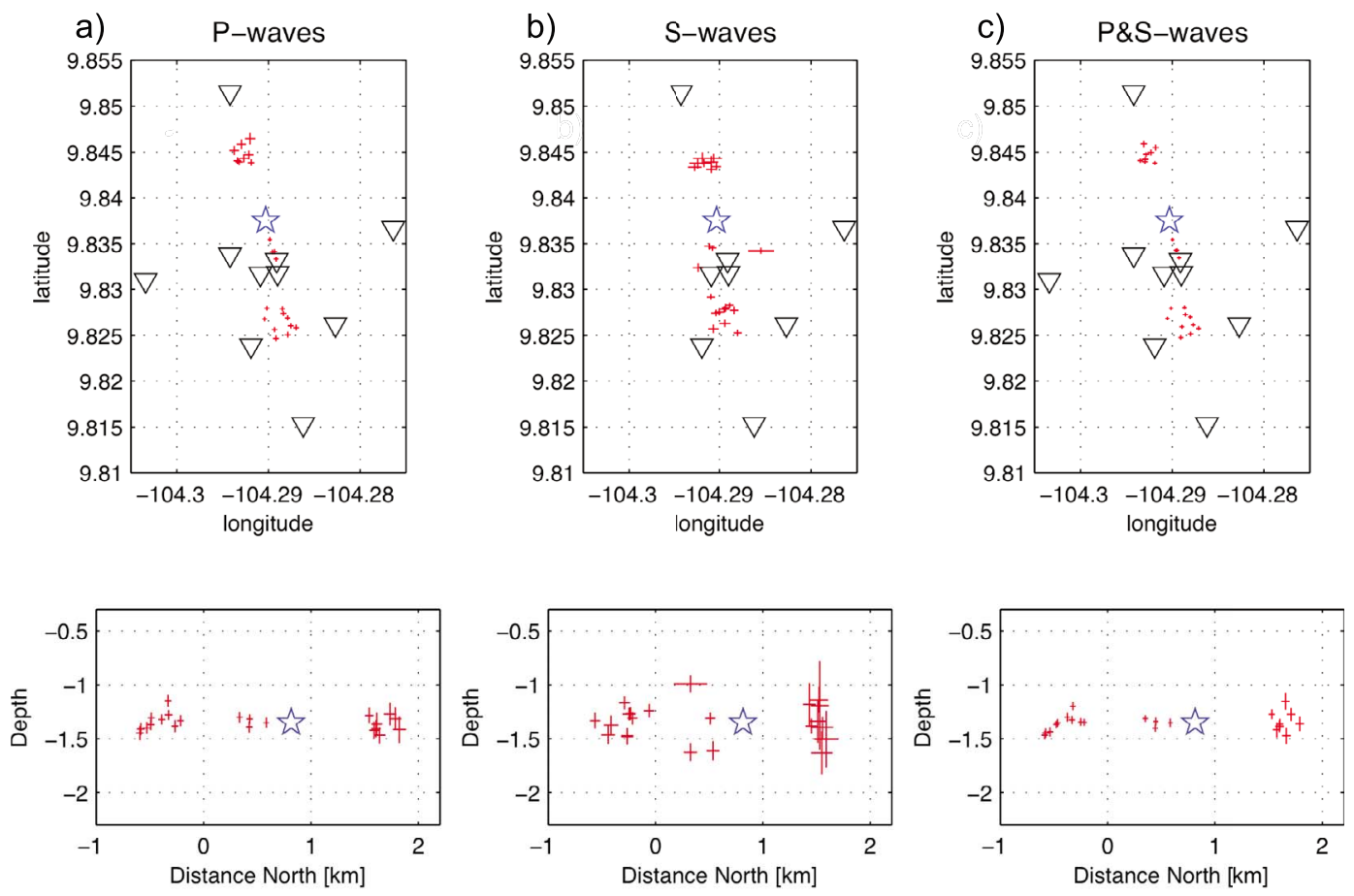

Figure A2. Testing robustness of delay time data. Earthquakes (22) relocated with (a) P wave differential times alone, (b) $\mathrm{S}$ wave, and (c) both $\mathrm{P}$ and $\mathrm{S}$ wave data. See text for details.

a severe error in absolute location (Figure A3b). We then relocate these shifted locations with hypoDD, allowing the algorithm to correct for potential bias in absolute location by removing the constraint on fixing the centroid location [Waldhauser and Ellsworth, 2000]. The result, shown in Figure A3c, moves the events back close to the original locations, demonstrating that the iterated hypoDD solu-
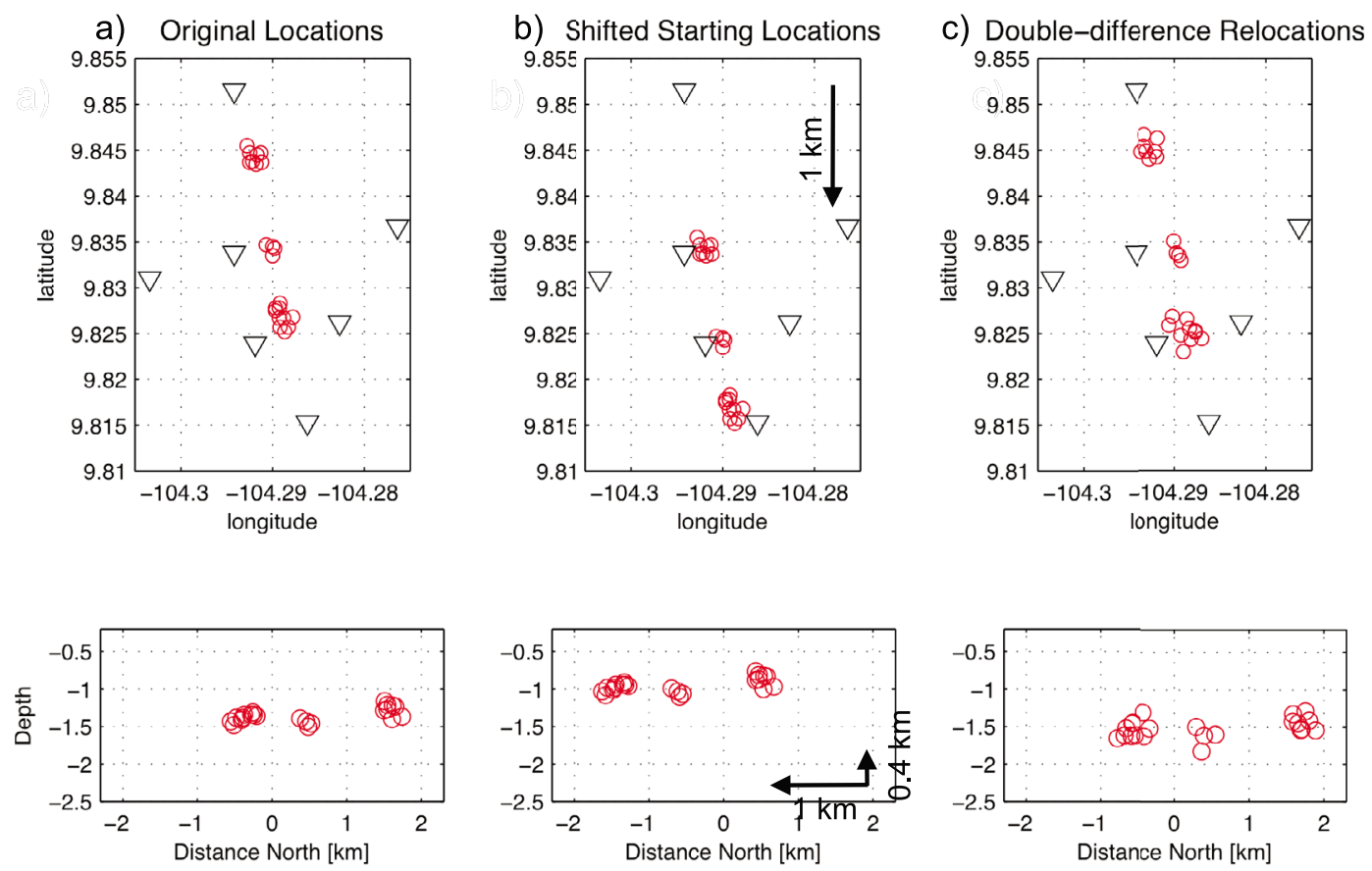

Figure A3. Testing robustness of absolute locations. (a) Original DD locations. (b) Shifted locations used as starting locations in hypoDD run. Arrows denote shift vectors. (c) DD relocations. See text for details. 
tions converge toward the absolute locations despite a gross absolute error in the starting locations. Furthermore, this test demonstrates the quality of the arrival time picks.

\section{Acknowledgments}

[31] We thank R. T. Weekly, D. R. Bohnenstiehl, and W. Y. Kim for their help in processing the OBS data and V. Ferrini for a copy of the side scan bathymetry data. We thank the captain, crew and science parties of the R/V Keldysh and R/V Atlantis. Discussions with S. Carbotte, R. Buck, and D. Hill and valuable comments and suggestions by W. Wilcock, an anonymous reviewer, and the Associate Editor significantly improved the manuscript. This work was supported by NSF grant OCE-032783, OCE-0732569, and OCE-0961594. This is LDEO contribution 7487.

\section{References}

Bohnenstiehl, D. R., F. Waldhauser, and M. Tolstoy (2008), Frequency-magnitude distribution of microearthquakes beneath the $9^{\circ} 50^{\prime} \mathrm{N}$ region of the East Pacific Rise, October 2003 through April 2004, Geochem. Geophys. Geosyst., 9, Q10T03, doi:10.1029/2008GC002128.

Carbotte, S. M., and K. C. Macdonald (1992), East Pacific Rise $8^{\circ}-10^{\circ} 30^{\prime} \mathrm{N}$ : Evolution of ridge segments and discontinuities from SeaMARC II and three-dimensional magnetic studies, J. Geophys. Res., 97, 6959-6982, doi:10.1029/ 91JB03065.

Combier, V., S. C. Satish, M. Cannat, and J. Escartin (2008), Mechanical decoupling and thermal structure at the East Pacific Rise axis $9^{\circ} \mathrm{N}$ : Constraints from axial magma chamber geometry and seafloor structures, Earth Planet. Sci. Lett., 272, 19-28, doi:10.1016/j.eps1.2008.03.046.

Cowen, J. P., et al. (2007), Volcanic eruptions at East Pacific Rise near $9^{\circ} 50^{\prime} \mathrm{N}$, Eos Trans. $A G U, 88,81$, doi:10.1029/ 2007EO070001.

Crone, T. J., M. Tolstoy, and D. Stroup (2011), Permeability structure of young ocean crust from poroelastically triggered earthquakes, Geophys. Res. Lett., 38, L05305, doi:10.1029/ 2011 GL046820.

deMartin, B., R. A. Sohn, J. P. Canales, and S. E. Humphris (2007), Kinematics and geometry of active detachment faulting beneath the Trans-Atlantic Geotraverse (TAG) hydrothermal field on the Mid-Atlantic Ridge, Geology, 35, 711-714, doi:10.1130/G23718A.1.

Dodge, D., G. C. Beroza, and W. L. Ellsworth (1995), Evolution of the 1992 Landers, California, foreshock sequence and its implications for earthquake nucleation, J. Geophys. Res., 100, 9865-9880, doi:10.1029/95JB00871.

Ferrini, V. L., D. J. Fornari, T. M. Shank, J. C. Kinsey, M. A. Tivey, S. A. Soule, S. M. Carbotte, L. L. Whitcomb, D. Yoerger, and J. Howland (2007), Submeter bathymetric mapping of volcanic and hydrothermal features on the East Pacific Rise crest at 9 $50^{\prime} \mathrm{N}$, Geochem. Geophys. Geosyst., 8, Q01006, doi:10.1029/2006GC001333.

Golden, C. E., S. C. Webb, and R. A. Sohn (2003), Hydrothermal microearthquake swarms beneath active vents at Middle Valley, northern Juan de Fuca Ridge, J. Geophys. Res., 108(B1), 2027, doi:10.1029/2001JB000226.
Gripp, A. E., and R. G. Gordon (2002), Young tracks of hotspots and current plate velocities, Geophys. J. Int., 150, 321-361, doi:10.1046/j.1365-246X.2002.01627.x.

Haymon, R. M., et al. (1993), Volcanic eruption of the midocean ridge along the East Pacific Rise crest at $9^{\circ} 45-52^{\prime} \mathrm{N}$ : Direct submersible observations of seafloor phenomena associated with an eruption even in April, 1991, Earth Planet. Sci. Lett., 119, 85-101, doi:10.1016/0012-821X(93)90008-W.

Julian, B. R., A. D. Miller, and G. R. Foulger (1997), Nondouble-couple earthquakes at the Hengill-Grensdalur geothermal area, southeast Iceland, Geophys. Res. Lett., 24, 743-746, doi:10.1029/97GL00499.

Kent, G. M., A. J. Harding, and J. A. Orcutt (1993), Distribution of magma beneath the East Pacific Rise between the Clipperton Transform and the $9^{\circ} 17^{\prime} \mathrm{N}$ deval from forward modelling of common depth point data, J. Geophys. Res., 98, 13,971-13,995, doi:10.1029/93JB00706.

Kissling, E., W. L. Ellsworth, D. Eberhart-Phillips, and U. Kradolfer (1994), Initial reference models in local earthquake tomography, J. Geophys. Res., 99, 19,635-19,646, doi:10.1029/93JB03138.

Klein, F. W. (2002), User's guide to HYPOINVERSE2000, a Fortran program to solve for earthquake locations and magnitudes, U.S. Geol. Surv. Open File Rep., 02-172, 123 pp.

Lowell, R. P., and Y. Yao (2002), Anhydrite precipitation and the extent of hydrothermal recharge zones at ocean ridge crests, J. Geophys. Res., 107(B9), 2183, doi:10.1029/ 2001JB001289.

Lutz, R. A., et al. (2008), Interrelationships between vent fluid chemistry, temperature, seismic activity, and biological community structure at a mussel-dominated, deep-sea hydrothermal vent along the East Pacific Rise, J. Shellfish Res., 27(1), 177-190, doi:10.2983/0730-8000(2008)27[177:IBVFCT] 2.0.CO;2.

McClain, J. S., M. L. Begnaud, M. A. Wright, J. Fondrk, and G. K. VonDamm (1993), Seismicity and tremor in a submarine hydrothermal field: The northern Juan de Fuca Ridge, Geophys. Res. Lett., 20, 1883-1886, doi:10.1029/ 93GL01872.

Pockalny, R. A., P. J. Fox, D. J. Fornari, K. C. Macdonald, and M. R. Perfit (1997), Tectonic reconstruction of the Clipperton and Siqueros fracture zones: Evidence and consequences of plate motion change for the last $3 \mathrm{Myr}$, J. Geophys. Res., 102, 3167-3181, doi:10.1029/96JB03391.

Poupinet, G., W. L. Ellsworth, and J. Fréchet (1984), Monitoring velocity variations in the crust using earthquake doublets: An application to the Calaveras fault, California, J. Geophys. Res., 89, 5719-5731, doi:10.1029/JB089iB07p05719.

Rubin, K. H., J. D. Macdougall, and M. R. Perfit (1994), ${ }^{210} \mathrm{Po}_{-}{ }^{210} \mathrm{~Pb}$ dating of recent volcanic eruptions on the sea floor, Nature, 368, 841-844, doi:10.1038/368841a0.

Schaff, D. P., G. Bokelmann, W. L. Ellsworth, E. Zanzerkia, F. Waldhauser, and G. C. Beroza (2004), Optimizing correlation techniques for improved earthquake location, Bull. Seismol. Soc. Am., 94, 705-721, doi:10.1785/0120020238.

Singh, S. C., and K. C. Macdonald (2009), Mantle skewness and ridge segmentation, Nature, 458(7241), E11-E12, doi:10.1038/nature07887.

Sohn, R. A., J. A. Hildebrand, and S. C. Webb (1999), A microearthquake survey of the high-temperature vent fields on the volcanically active East Pacific Rise $\left(9^{\circ} 50^{\prime} \mathrm{N}\right), \mathrm{J}$. Geophys. Res., 104, 25,367-25,377, doi:10.1029/1999JB900263.

Stroup, D. F., D. R. Bohnenstiehl, M. Tolstoy, F. Waldhauser, and R. T. Weekly (2007), Pulse of the seafloor: Tidal trig- 
gering of microearthquakes at $9^{\circ} 50^{\prime} \mathrm{N}$ East Pacific Rise, Geophys. Res. Lett., 34, L15301, doi:10.1029/ 2007GL030088.

Stroup, D. F., M. Tolstoy, T. J. Crone, A. Malinverno, D. R. Bohnenstiehl, and F. Waldhauser (2009), Systematic along-axis tidal triggering of microearthquakes observed at $9^{\circ} 50^{\prime} \mathrm{N}$ East Pacific Rise, Geophys. Res. Lett., 36, L18302, doi:10.1029/2009GL039493.

Tanaka, S., M. Ohtake, and H. Sato (2002), Evidence for tidal triggering of earthquakes as revealed from statistical analysis of global data, J. Geophys. Res., 107(B10), 2211, doi:10.1029/2001JB001577.

Tolstoy, M., et al. (2006), A sea-floor spreading event captured by seismometers, Science, 314, 1920-1922, doi:10.1126/science.1133950.

Tolstoy, M., F. Waldhauser, D. R. Bohnenstiehl, R. T. Weekly, and W.-Y. Kim (2008), Seismic identification of along-axis hydrothermal flow on the East Pacific Rise, Nature, 451, 181-184, doi:10.1038/nature06424.

Toomey, D. R., D. Jousselin, R. A. Dunn, W. S. D. Wilcock, and R. S. Detrick (2007), Skew of mantle upwelling beneath the East Pacific Rise governs segmentation, Nature, 446, 409-414, doi:10.1038/nature05679.

Toomey, D. R., D. Jousselin, R. A. Dunn, W. S. D. Wilcock, and R. S. Detrick (2009), Toomey et al. reply, Nature, 458, 7241, E12-E13, doi:10.1038/nature07888.
Van Decar, J. C., and R. S. Crosson (1990), Determination of teleseismic relative phase arrival times using multi-channel cross-correlation and least-squares, Bull. Seismol. Soc. Am., 80, 150-169.

Vera, E. E., J. C. Mutter, P. Buhl, A. J. Harding, J. A. Orcutt, A. J. Harding, M. E. Kappus, R. S. Detrick, and T. M. Brocher (1990), The structure of 0- to 0.2-m.y.-old oceanic crust at $9^{\circ} \mathrm{N}$ in the East Pacific Rise from expanded spread profiles, J. Geophys. Res., 95, 15,529-15,556, doi:10.1029/ JB095iB10p15529.

Waldhauser, F. (2001), HypoDD: A computer program to compute double-difference earthquake locations, U.S. Geol. Surv. Open File Rep., 01-113.

Waldhauser, F., and W. L. Ellsworth (2000), A doubledifference earthquake location algorithm: Method and application to the northern Hayward fault, Bull. Seismol. Soc. Am., 90, 1353-1368, doi:10.1785/0120000006.

Wilcock, W. S. D., S. D. Archer, and G. M. Purdy (2002), Microearthquakes on the Endeavour segment of the Juan de Fuca Ridge, J. Geophys. Res., 107(B12), 2336, doi:10.1029/2001JB000505.

Wilcock, W. S. D., E. E. E. Hooft, D. R. Toomey, P. R. McGill, A. H. Barclay, D. S. Stakes, and T. M. Ramirez (2009), The role of magma injection in localizing blacksmoker activity, Nat. Geosci., 2, 509-513, doi:10.1038/ ngeo550. 